\author{
SEAWOMIR ŁODZIŃSKI \\ UNIWERSYTET WARSZAWSKI \\ S.LODZINSKI@UW.EDU.PL
}

\title{
ETNICZNE „FLAGOWANIA” RZECZYWISTOŚCI. PROBLEMY WPROWADZANIA DODATKOWYCH NAZW MIEJSCOWOŚCI W JĘZYKACH MNIEJSZOŚCI NARODOWYCH W POLSCE
}

\section{Uwagi wstępne}

Przyjęta przez Sejm 6 stycznia 2005 roku ustawa o mniejszościach narodowych i etnicznych oraz języku regionalnym (dalej jako ustawa o mniejszościach) wprowadziła do polskiego prawa regulacje dotyczące między innymi możliwości stosowania dodatkowych nazw miejscowości w językach mniejszości narodowych i języku regionalnym (kaszubskim), [Ustawa..., 2005]. Były one dużą innowacją dla administracji publicznej (zwłaszcza gminnej), gdyż takie rozwiązania dotychczas nie występowały jeszcze w naszym kraju. Stanowiły one również wyzwanie dla społeczności lokalnych, gdyż obawiano się ujawnienia się w nich podziałów etnicznych "mniejszość - większość". Budziły one dodatkowo negatywne skojarzenia historyczne. Badania opinii publicznej wskazywały raczej na niechętny jej stosunek wobec instalowania „dwujęzycznych” nazw. Według sondażu przeprowadzonego na początku 2005 roku 63\% badanych było przeciw umieszczania tablic z nazwami miejscowości w językach mniejszości obok tablic $\mathrm{z}$ nazwami polskimi, a $26 \%$ je popierało ( $11 \%$ badanych udzieliło odpowiedzi „trudno powiedzieć”). Po dziesięciu latach od uchwalenia ustawy o mniejszościach i wprowadzenia dwujęzycznych nazw opinia na ich temat niewiele się zmieniła. W 2015 roku nadal większość badanych - 60\% była im przeciwna, a popierało je $32 \%$ badanych (choć warto odnotować wzrost 
akceptacji o $6 \%$ w stosunku do 2005 roku), a $8 \%$ udzieliło odpowiedzi „trudno powiedzieć [CBOS 2015: 5] ${ }^{1}$.

Obecność dodatkowych nazw miejscowości w językach mniejszości wskazuje na ważną społecznie rolę języka w określaniu tożsamości w regionach zróżnicowanych etnicznych we współczesnej Polsce. Stały się one dla grup mniejszościowych wizualnymi i publicznymi znakami ich odrębności etnicznej ustalając "granice symboliczne” w społeczności lokalnej [Donan, Wilson 2007: 41]. Rozumiemy je tutaj jako rodzaj „konceptualnych dystynkcji”, tworzonych przez aktorów społecznych, które „dzielą ludzi do grup, rodząc poczucie podobieństwa i grupowej przynależności” [Lamont, Molnar 2002: 168]. Z perspektywy życia codziennego nazwy te pełnią funkcje etnicznego „flagowania” rzeczywistości i zdarza się, że stają się one nie tylko przedmiotem banalnego nacjonalizmu, ale również jego "gorącej” wersji [Billig 2008: 92-97, 175-179].

Lokalne granice etniczne tworzone na bazie odrębności językowej praktycznie nie występowały w Polsce do 1989 roku. Były one publicznie niewidoczne, ograniczone głównie do nauki uznanych języków mniejszości w szkołach oraz imprez folklorystycznych. Prowadzonej polityce asymilacyjnej wobec mniejszości ( $\mathrm{z}$ różnym natężeniem $\mathrm{w}$ poszczególnych okresach historii powojennej) sprzyjały również procesy zmian społeczno-gospodarczych w Polsce, a zwłaszcza industrializacja, migracje ze wsi do miast i ekspansja kultury masowej w języku polskim (głównie radio i telewizja), a także narodowa (polonizująca) rola Kościoła katolickiego. Te wszystkie zjawiska wzmacniały naturalne procesy asymilacji językowej mniejszości narodowych i rozwój dominacji polskiego języka literackiego kosztem innych języków mniejszościowych oraz gwar [Szul 2009: 259; Kamusella 2009: 620-628]. Z perspektywy językowej trudno więc było mówić o widocznej odróżnialności grup i rejonów zróżnicowanych etnicznie-językowo w naszym kraju.

1 Dodajmy, że w świetle tego sondażu w stosunku do 2005 roku nastąpił także wzrost odsetka osób twierdzących, że członkowie mniejszości narodowych i etnicznych powinni mieć możliwość porozumiewania się w swoim języku w urzędach lokalnych w miejscowościach, w których mieszkają (z 37\% do 41\%), choć nadal niewielką przewagę mają tutaj opinie negatywne (z 52\% do 51\%). W tym komunikacie zapisano także, że osoby znające kogoś należącego do mniejszości (lub same będące jej członkami) częściej niż pozostali badani zgadzają się na przyznanie mniejszościom narodowym prawa do: nauki swojego języka na dodatkowych lekcjach ( $83 \%$ wobec $77 \%$ ), umieszczania tablic z nazwami miejscowości we własnym języku obok tablic z nazwami polskimi (37\% wobec $31 \%$ ), otrzymywania pomocy finansowej od państwa na podtrzymywanie własnej kultury, tradycji (48\% wobec $41 \%)$, [CBOS 2015]. 
Po 1989 roku sytuacja się zmieniła, gdyż demokratyzacja ustrojowa dała większe możliwości swobodnego głoszenia przynależności do grup mniejszościowych, wprowadzone uregulowania prawne dotyczące praw mniejszości rozwijały szanse rozwoju i reprodukcji ich tożsamości kulturowej, a bardziej swobodne i mniej polityczne kontakty z krajami ojczystymi dodatkowo je wzmacniały. Istotnym elementem działalności organizacji mniejszości były dążenia do silniejszego publicznego zaznaczenia swojej obecności na danym terenie przez wprowadzanie swoich narodowych i religijnych znaków w krajobrazie. Objęło to właściwie każdą grupę mniejszościową w Polsce. Zdaniem Marka Dziewierskiego, piszącego o praktykach symbolicznych w przestrzeni na podstawie doświadczeń Ukraińców grekokatolików, można określić to zjawisko mianem „ideologicznej reifikacji krajobrazu”. Składają się na nią odwołania między innymi do tradycyjnego krajobrazu geograficznego (na przykład gór, lasów), obecności odmiennych od katolickich symboli religijnych (na przykład trójramiennego krzyża), odrębnej architektury (na przykład cerkwi), tworzenia miejsc pamięci i „miejsc świętych” (na przykład spacyfikowanej przez wojsko polskie w 1946 roku wsi Zawadki Morochowskiej w województwie podkarpackim), instalowania tablic upamiętniających ważne wydarzenia $\mathrm{z}$ historii grupy (Akcja Wisła) i zasłużone osoby dla jej kultury [Dziewierski 2008: 7-12].

Wszystkie rozwijają silnie poczucie „bycia u siebie” i tworzenia własnych „miejsca znaczących” („etnicznych”) rozumianych jako lokalizacja wartości o etnicznym i narodowym charakterze, będące dla grupy ceremonialnym punktem kulturowych odniesień i pamięci kolektywnej, budzące silne emocje osobiste i grupowe [Edensor 2004: 65-68]. Miejsca takie stają się społecznie wyraziste dzięki, zdaniem Yi-Fu Tuana, „rozmaitym środkom: rywalizacji i konfliktom z innymi miejscami, walorami widokowymi, ewokacyjnej sile sztuki, architektury, obrzędów i rytów" [Tuan 1987: 223].

Dla wykreowania takiego typu miejsca ważnym sposobem staje się język oraz sposób opowiadania o nim. Czy opowiada się o nim w języku mniejszości, czy jest ono obecne w literaturze, popularnych piosenkach, wspomnieniach, a także $\mathrm{w}$ naukowych dziełach $\mathrm{z}$ etnohistorii? Istotnym elementem staje się tutaj odrębna toponomastyka tych miejsc. Sposób ich określania i nadawania im konkretnych nazw jest bowiem takim rodzajem władzy, która „posiada moc powoływania rzeczy do istnienia, przedstawiająca niewidoczne jako widoczne, nadająca im określone cechy” [Tuan 1991: 688]. 
To szczególne powiązanie kultury i pamięci grupy z kreowaniem znaków grupowych w przestrzeni możemy określić za Lechem M. Nijakowskim pojęciem „domeny symbolicznej”, czyli terytorium, nad którym dana grupa lub też konkurujące ze sobą grupy dążą do panowania nad „rzeczami, które są ważnymi symbolami i znakami dla danej grupy” [Nijakowski 2007: 111]. Mogą do nich należeć pomniki, tablice, budynki, obiekty kultu oraz także nazwy miejsc w językach mniejszości („krajobraz semantyczny”), będącymi ważnymi symbolami tożsamości grupowej, zawłaszczającymi obieg pamięci na danym terenie [Nijakowski 2007: 173-181]. Podkreślmy, że owo panowanie symboliczne nie tylko ma znaczenie tożsamościowe, ale staje się także elementem działalności politycznej i władzy na danym terenie i może rodzić konflikty. Jak istotne mogą być te problemy może o tym świadczyć artykuł Agnieszki Pasieki opisujący spór związany z ustalaniem dodatkowej nazwy w języku łemkowskim w miejscowości Bielanka (powiat gorlicki). Została ona tam wprowadzona w ramach lokalnych konsultacji społecznych przewagą tylko jednego głosu, co spowodowało trwały podział w tej małej społeczności. Autorka podkreśliła, że głosowanie nad łemkowską nazwą dotyczyło czegoś więcej niż „tylko kilku liter” [Pasieka 2013: 152].

Artykuł próbuje podejmować problematykę teoretyczną przedstawioną wyżej. Jego celem jest opis problemów związanych z wprowadzaniem „dwujęzycznych” nazw miejscowości na poziomie samorządu terytorialnego. Będę się starał wykazać w nim, że ich pojawienie się w gminach „mniejszościowych” stanowiło z jednej strony publiczne potwierdzenie istniejącego tam od dawna zróżnicowania etnicznego. Zaczęły one pełnić rolę etnicznych „markerów” zakreślających granice przynależności do określonej grupy etnicznej i terenu, na którym ona żyje, a także zaświadczających o jej pozycji oraz jej języka i kultury na poziomie lokalnym. Z drugiej strony „mniejszościowe” nazewnictwo dawało możliwości budowy społeczności wielokulturowych, w których różnice etniczne są uznawane oraz popierane przez władze lokalne. Nie był to jednak proces łatwy, gdyż ich „stawianie” prowadziło niejednokrotnie do lokalnych sporów i konfliktów (widocznych między innymi w częstym zamalowywaniu na tablicach dodatkowych nazw miejscowości). Jednocześnie uzyskana „dwujęzyczność” stawała się niejednokrotnie element kreowanego „wielokulturowego” wizerunku gminy oraz jej promocji.

Opis procesu wprowadzania dodatkowych nazw w językach mniejszości na poziomie lokalnym może być potraktowany jako świadectwo trudności przemian społeczeństwa polskiego jako zróżnicowanego kulturowo 
i etnicznie w kierunku społeczeństwa pluralistycznego, otwartego na grupy mniejszościowe, ich języki i odmienną symbolikę [Sadowski 2014: 33-47]. Andrzej Sadowski podkreśla, że empirycznym kluczem do badania takich przeobrażeń może być poszukiwanie odpowiedzi na pytanie, „jak poszczególni aktorzy, indywidualni i zbiorowi, radzą sobie ze zróżnicowaniem kulturowym (lub ewentualnie także z pluralizmem kulturowym" [Sadowski 2011: 51]. Dla nas takim głównym aktorem była gmina oraz jej władze (rada gminy), podejmująca decyzje o wprowadzaniu dodatkowych nazw miejscowości w językach mniejszości [Plewko 2009: 102-147].

Porządek artykułu jest następujący. Na początku przedstawię problemy badania nazw w językach mniejszości narodowych (między innymi przez koncepcję „krajobrazu językowego”), następnie opiszę regulacje ich wprowadzania na podstawie ustawy o mniejszościach i wynikające z nich zadania dla samorządu terytorialnego, dalej charakter społeczno-demograficzny i polityczny „dwujęzycznych” gmin, a na zakończenie będę próbował ukazać różnice $\mathrm{w}$ ich znaczeniu dla różnych grup mniejszościowych. W artykule opieram się na analizie wniosków rad „gmin mniejszościowych” o nadanie dodatkowych nazw miejscowości oraz wywiadów z przedstawicielami ich władz ${ }^{2}$.

\section{Dodatkowe nazwy miejscowości w językach mniejszości narodowych w sferze publicznej}

Pochodzenie i zmienności nazw miejscowych (place names; nazw geograficznych) stanowi od dawna przedmiot zainteresowania toponomastyki (traktowanej jako dział onomastyki w ramach ogólnego językoznawstwa). Nazwy te, określane także często mianem „toponimów” (od grec. topos - 'miejsce') dotyczą wszystkich obiektów fizjograficznych zamieszkałych bądź niezamieszkałych przez ludzi, w tym również nazewnictwa w ramach jednostek administracyjnych, takich jak miasta i wsie (nazwy urzędowe). Doczekały się one ogromnej literatury naukowej, zwłaszcza językoznawczej

2 W artykule wykorzystuję materiały, które zostały zebrane w ramach projektu „Nazwy i granice etniczne. Problemy wprowadzania dwujęzycznych nazw miejscowości w Polsce na podstawie ustawy o mniejszościach z 2005 roku”. Projekt ten został sfinansowany ze środków Narodowego Centrum Nauki przyznanych na podstawie decyzji numer DEC-2011/03/B/HS6/01648. Chciałbym w tym miejscu gorąco podziękować za pomoc w dostępie do oficjalnej dokumentacji związanej z wprowadzeniem dwujęzyczności pani Annie Szustakiewicz i panu naczelnikowi Dobiesławowi Rzemieniewskiemu z Departamentu Wyznań Religijnych oraz Mniejszości Narodowych i Etnicznych Ministerstwa Administracji i Cyfryzacji. 
koncentrującej się głównie na analizach ich historycznej genezy i ewolucji [Handke 2009: 321-372].

$\mathrm{W}$ artykule interesuje mnie jednak nie tyle językowa strona nazw miejscowości, ile sposób ich wprowadzania oraz przypisywane im znaczenia społeczne i kulturowe. Nazwy stanowią bowiem przedmiot różnorodnych znaczeń społecznych, stając się przy tym często obiektem kontrowersji społecznych i politycznych. Jest to związane z pełnieniem przez nie również funkcji symbolicznych, podkreślających ich rolę w umacnianiu identyfikacji ludzi z danym „miejscem” oraz w kształtowaniu tożsamości zbiorowej jego mieszkańców. Jak pisze amerykański geograf kulturowy Derek H. Alderman, nazwy miejscowe „nie tylko łączą historię z geografią, ale także starają się połączyć miejsce i tożsamość grupową z powodu wspólnego kontekstu stosowania i odwoływania się do określonych toponimów" [Alderman 2008: 196; por. Czerny 2011: 99-100]. Właśnie z powodu roli symbolicznej odgrywanej przez nazwy miejscowe zaczęto się interesować mechanizmami "nadawania nazw” (naiming), w ramach których szczególną uwagę zaczęto przywiązywać do wpływu polityki i ideologii, zmian ustrojowych oraz wartości, jakie poszczególne nazwy mogą stanowić dla ludzi. Na pierwszy plan wysunęła się rola nazw w procesach konstruowania dziedzictwa narodowego i tożsamości zbiorowych. Badania te łączy ogólne przekonanie, że normatywne nadawanie nazw tworzy określony „materialny i symboliczny wzór, który pozwala dominującym grupom narzucać określone znaczenia w krajobrazie i stąd kontrolować symboliczną identyfikację ludzi i miejsc" [Alderman 2008: 208]. W Polsce badania w tej dziedzinie dotyczyły przede wszystkim nazewnictwa miejscowości i nazewnictwa miejskiego (zwłaszcza nazw ulic i przestrzeni publicznej). Zaświadczają o tym także liczne prace językoznawcze, geograficzne oraz socjologiczne dotyczące takich zmian w Polsce po przełomie ustrojowym w 1989 roku [Hałas 2004; Kaltenberg-Kwiatkowska 2011].

Kwestie te stają się szczególnie interesujące w wypadku analiz nazw w językach mniejszości narodowych, odmiennych od języka (języków) oficjalnego danego państwa. Studia nad nimi są uprawiane między innymi w ramach koncepcji „krajobrazu językowego” (linguistic landscape), w ramach której nie tylko zbiera się informacje na temat językowych zmian „szaty informacyjnej” miast i miejscowości (między innymi nazw ulic, urzędów, przedsiębiorstw, itp.), ale analizuje się także społeczne i polityczne reakcje na zwiększającą się „różnorodność” językową społeczeństw [Landry, Bourhis 1997]. Znaczenie ma tutaj badanie zarówno języków „starych” (autochtonicznych), jak i „nowych” (imigranckich) mniejszości, 
a także unikalnych, ginących języków (mikrojęzyków) lub lokalnych odmian (wysp) języków mniejszościowych [Wicherkiewicz 2014: 72-77; Blommaert 2013]. Próbuje się tutaj zbierać i analizować wszelkie mniejszościowe, tekstowe (napisy) manifestacje językowe w przestrzeni publicznej od prywatnych i komercyjnych do urzędowych i oficjalnych. Choć publiczna i wizualnie dostrzegalna obecność tych przejawów językowych ma charakter ograniczony i głównie symboliczny, to jest jednak traktowana przez mniejszość jako uznanie jej równego statusu wobec języka większości (języka oficjalnego) na danym terenie [Dołowy-Rybińska 2013: 129].

Można zadać pytanie, dlaczego poszukiwanie i dążenie do wprowadzania różnych form dostrzegalności języka mniejszości w krajobrazie językowym, a w tym zwłaszcza dodatkowych nazw miejscowości, jest tak ważnym zadaniem dla organizacji mniejszości? Można wskazać na następujące przyczyny [Marten, Mensel, Gorter 2012: 1-8]. Po pierwsze, wynika ona z faktu „oficjalności' wielojęzycznych znaków, gdyż ich postawienie nie jest tylko zwykłą czynność techniczną (drogową) lub administracyjną, lecz stanowi ważny akt uznania zróżnicowanego dziedzictwa historycznego danego miejsca i jego językowo-etnicznego zróżnicowania. Po drugie, ze względu na pozycję samych grupy mniejszościowych, ich tożsamość etniczną oraz żywotność ich języków. Instalacja i wizualna dostępność nazw miejscowości w ich językach odzwierciedla nie tylko charakter demograficzno-językowy danego miejsca (regionu), ale wpływa pozytywnie na status i prestiż jego użytkowników. Po trzecie, ze względu na znaczenie polityki państwa wobec języków mniejszości oraz aktywność samych mniejszościowych organizacji etnicznych. Podkreśla się tutaj z jednej strony rolę oficjalnej polityki językowej, dostarczającej reguł upowszechniania dodatkowego nazewnictwa w językach mniejszości (spojrzenie „od góry”), a z drugiej strony wagę ich wpływu na utrzymanie żywotności tych języków (spojrzenie „od dołu”). Po czwarte wreszcie, ze względu na społeczne reakcje wobec wzrastającej wizualnie różnorodności danego miejsca oraz pojawiające się z tym kontestacje oraz konflikty. Badaczy interesują tutaj zwłaszcza sposoby, jakie stosuje społeczność lokalna, agencje państwowe i organizacje mniejszościowe do radzenia sobie ze złożoną rzeczywistością społeczną oraz „grą symboli” językowych. Podkreślają oni, że w lokalnych relacjach większość-mniejszość negocjacja „władzy symbolicznej bądź realnej jest włączona oraz dokonuje się poprzez obecność języka ... w sferze publicznej" [Marten, Mensel, Gorter 2012: 6]. Stanowi to szczególne wyzwanie dla organizacji mniejszości i jej reprezentacji politycznej we władzach lokalnych, gdyż starania te są nie tylko formą walki o spełnie- 
nie ich szczególnych uprawnień, ale także o spójność grupy i uznanie jej odrębnej tożsamości.

To zwiększone zainteresowanie publiczną obecnością języków mniejszości stanowi również wynik rozszerzenia zasięgu europejskich standardów ochrony praw osób należących do mniejszości narodowych w ostatnich dwóch dekadach [Nijakowski 2014]. Wiąże się to z przyjęciem dwóch ważnych dokumentów w tej dziedzinie (w ramach Rady Europy): Europejskiej Karty Języków Regionalnych i Mniejszościowych (1992) i Konwencji Ramowej Rady Europy o Ochronie Mniejszości Narodowych. Jako jedną z zasad przyjmują one, że język ojczysty pozostaje jednym z najważniejszych czynników tożsamości oraz identyfikacji etnicznej osób należących do mniejszości narodowych. Nie ma tutaj znaczenia ani stopień jego znajomości (czyli biegłość i kompetencja w posługiwaniu się tym językiem), ani też stopień jego używania w życiu społecznym i publicznym [The language rights of... 2012: 6-7]. W zakresie dodatkowego nazewnictwa geograficznego i nazw miejscowości uznają one, że na obszarach zamieszkałych tradycyjnie lub w znaczącej liczbie przez osoby należące do mniejszości narodowej (o ile one sobie tego zażyczą), władze państwa będą tworzyć odpowiednie warunki prawne dla ich wprowadzenia.

Ich realizacja na poziomie krajowym i poszczególnych już społeczności lokalnych napotyka duże trudności. Wynika ona nie tylko z ogólnikowych i ramowych ich określeń, ale również z braku jasnych wskazówek, co może stanowić „minimalne standardy” w tej dziedzinie oraz jakie „dobre praktyki” z innych krajów mogą stanowić przykład dla innych krajów. Sprawia również problemy polityczne, gdyż regulacje dotyczące dwujęzycznych nazwy miejscowości wprowadzają wyraźną „inność” językowo-etniczną, naruszającą w sposób widoczny jednolitość kulturową (językową) i narodową danego obszaru. Dlatego oczekiwania ich realizacji były i są często interpretowane przez większość jako dążenie danej mniejszości do uzyskania autonomii terytorialnej [Godlewska 2014: 162-163]. Ich implementacja pozostaje również skomplikowana ze względów legislacyjnych (konkretnych sposobów ich regulacji w prawie krajowym) oraz możliwych wysokich kosztów finansowych ich wprowadzenia. Jak pouczają przykłady z różnych państw wprowadzanie mniejszościowych uprawnień językowych nigdy nie było łatwe i prowadziło często do długotrwałych konfliktów. 


\section{Dodatkowe nazwy miejscowości w językach mniejszości narodowych a samorząd terytorialny w Polsce}

Regulacje dotyczące dwujęzycznych, polskich i „mniejszościowych”, nazw miejscowości praktycznie nie istniały w Polsce aż do przyjęcia ustawy o mniejszościach w 2005 roku. Nie funkcjonowały one ani w okresie międzywojennym (1918-1939), ani też w okresie powojennym. Pierwsze propozycje ich wprowadzenia znalazły się w projektach ustawy o mniejszościach, przygotowywanej od początku lat dziewięćdziesiątych XX wieku. Budziła ona jednak duże opory polityczne i została dopiero przyjęta w styczniu 2005 roku [Adamczyk, Sakson, Trosiak 2015]. Przyniosła ona między innymi szczegółowe regulacje dotyczące praw językowych osób należących do mniejszości, które obejmowały pisownię imion i nazwisk zgodnie z zasadami ojczystego języka mniejszości (art. 7), prawo do swobodnego posługiwaniu się nim w życiu prywatnym i publicznie (art. 8), dopuszczenia go do używania jako pomocniczego przed organami gminy (art. 9-11) oraz możliwości wprowadzania dodatkowych, tradycyjnych nazw miejscowości, obiektów fizjograficznych oraz ulic w tym języku, obok obowiązujących urzędowych nazw w języku polskim (art. 12-15). Zasady te miały być również stosowane wobec języka kaszubskiego, który został określony w ustawie jako język regionalny, zgodnie z definicją znajdującą się w Europejskiej Karcie Języków Regionalnych lub Mniejszościowych [Janusz 2015: 15-24].

Bardziej szczegółowo zasady dotyczące stosowania dodatkowych nazw stanowią, że mogą być one używane tylko na obszarze gmin, które zostały wpisane do specjalnego rejestru (dokładnie „Rejestru Gmin, na których obszarze używane są nazwy w języku mniejszości”, dalej jako rejestr), nie mogą one nawiązywać do nazw z okresu 1933-1945 nadanych przez władze Rzeszy Niemieckiej lub ZSRR oraz muszą być umieszczane po nazwie polskiej (nie mogą być one stosowane samodzielnie). Dotyczą one tylko tych gmin, w których liczba mieszkańców gminy należących do mniejszości jest nie mniejsza niż 20\% ogólnej jej liczby (ustalanej według wyników ostatniego spisu powszechnego ludności) lub gdy, za ustaleniem dodatkowej nazwy miejscowości w języku mniejszości opowiedziała się w trakcie konsultacji ponad połowa (większość) uczestniczących w nich mieszkańców. Dodatkowe nazwy mogą być wprowadzone na terenie całej gminy lub w poszczególnych miejscowościach. Koszty z tym związane ponosi budżet państwa, ale wprowadzenie dodatkowych nazw ulic i dwujęzycznych tablic na urzędach obciąża już budżet gminy (art. 15). 
Sama procedura wprowadzania dodatkowych nazw wygląda następująco. Rada gminy podejmuje uchwałę, aby gmina została wpisana do rejestru oraz - jeżeli to konieczne - również decyzję o przeprowadzeniu konsultacji społecznych dotyczących tych nazw. Rada na tym etapie może wystąpić również o weryfikację językową i historyczną proponowanych nazw do wyspecjalizowanych instytucji naukowych, a także przygotować kosztorys ustawienia dwujęzycznych tablic. Następnie kieruje ona ten wniosek (dla każdej dodatkowej nazwy miejscowości oddzielny) zawierający dane urzędowe o ogólnej liczbie mieszkańców gminy oraz liczbie (odsetku) mieszkających na jej terenie osób należących do mniejszości (na podstawie wyników ostatniego spisu powszechnego) wraz uchwałą rady gminy o wprowadzeniu dodatkowych nazwach do właściwego ministerstwa za pośrednictwem odpowiedniego wojewody (obecnie jest to Ministerstwa Spraw Wewnętrznych i Administracji, a wcześniej było to Ministerstwo Administracji i Cyfryzacji). Ono z kolei zwraca się o opinię na temat prawidłowości nazw do Komisji Nazw Miejscowości i Obiektów Fizjograficznych. Zgodnie z prawem minister ma 90 dni na dokonanie wpisu gminy do rejestru, a cała procedura trwa zazwyczaj około jednego roku.

$\mathrm{Z}$ perspektywy całego tego procesu najważniejsze było przyznanie w ustawie o mniejszościach decydującej roli gminom, zwłaszcza radom gmin, w ich wprowadzaniu. To one miały decydować, czy w ogóle wprowadzać nazwy dodatkowe na jej terenie. Jeżeli tak, to w ilu i w jakich miejscowościach? Czy należy przeprowadzić konsultacje społeczne, aby uzyskać dla nich akceptację mieszkańców? Czy i kiedy można wprowadzić dodatkowe nazwy ulic lub obiektów geograficznych? To właśnie władze lokalne stały się głównymi „aktorami” ich instytucjonalizacji, a na ich decyzje mógł wpływać ich profil etniczny, czyli obecność mniejszości na ich terenie, jej zorganizowanie i mobilizacja oraz historia wzajemnych kontaktów. Władze centralne miały jedynie nadzorować prawidłowy przebieg procedury i wydatkowania funduszy oraz sprawdzać poprawność historyczną proponowanych nazw.

Taki sposób organizacji przenosi ciężar wprowadzania dodatkowych nazw na poziom władz lokalnych i różnicuje go od samego charakteru gmin. To one wraz z lokalnymi organizacjami mniejszości mogą być wiodącymi aktorami ich implementacji, mimo że nie miały one bezpośredniego wpływu na proces stanowienia ustawy o mniejszościach na poziomie centralnym i przyjęty tam kształt konkretnych rozwiązań administracyjnych. Posiadają one swobodę decydowania o wprowadzeniu ich w życie, a także mogą wpływać i kontrolować przebieg lokalnego procesu przyj- 
mowania tych nazw [Balzas, Schwellnus 2014: 107-108]. W wypadku ich pozytywnego wprowadzenia mogą je przedstawiać jako „własny” sukces, a odpowiedzialność za niepowodzenie lub opóźnienie próbować przenieść na „niechęć” większości wobec takich praw lub podkreślać brak odpowiednich warunków politycznych dla ich implementacji. Sprawia to, że ochrona ważnej części praw mniejszości, jakim są prawa językowe, staje się przedmiotem ich samodzielnych decyzji oraz rodzajem ich podmiotowej „samoochrony" mniejszości [Malloy 2005: 313].

Dlatego przyjęcia rozwiązań dotyczących dwujęzycznych nazw możemy oczekiwać w tych gminach, gdzie mniejszości są znaczącą siłą demograficzną (stanowią ważną część lokalnej społeczności, zgodnie z ustawą o mniejszościach minimum $20 \%$ całej populacji gminy), dobrze zorganizowaną i zmobilizowaną społecznie (co może mieć wpływ na przebieg i wynik konsultacji społecznych dotyczących nazw) oraz posiadającą reprezentację polityczną we władzach lokalnych. W takiej sytuacji brak wprowadzenia nazw (lub opóźnienia w ich stawianiu) mogą być wyzwaniem dla władz lokalnych, gdyż trudno im będzie ignorować oczekiwania mniejszości.

Dlatego dużą rolę odgrywa tutaj reprezentacja polityczna mniejszości w radach gmin, która dąży do uwzględniania jej interesów i oczekiwań kulturowych oraz poprzez głosowanie wpływa na podejmowane decyzje. Od lat dziewięćdziesiątych ubiegłego wieku przedstawiciele mniejszości są obecni we władzach lokalnych w Polsce. Mimo początkowego dystansowania się wobec nich z czasem stały się one ważnym, a obecnie najbardziej istotnym forum publicznej reprezentacji ich interesów [Bojar 1996: 417-418]. Zdaniem Ewy Ganowicz pełną aktywność polityczną mniejszości narodowych $\mathrm{w}$ Polsce można dopiero zaobserwować na poziomie samorządu terytorialnego, gdzie wykorzystują one „niepartyjne formy ekspresji politycznej”, tworząc własne komitety wyborcze o charakterze obywatelskim [Ganowicz 2013: 26, 38-39]. Wyraża się ona przede wszystkim w licznym udziale jej liderów w wyborach do rad gmin, powiatów i sejmiku wojewódzkiego.

Biorąc pod uwagę czas obowiązywania ustawy o mniejszościach od 2005 roku można zapytać o reprezentację mniejszości we władzach lokalnych. W wyborach samorządowych z 2006 roku 420 przedstawicieli mniejszości narodowych i etnicznych znalazło się w składach rad gmin, a 32 zostało wójtami i burmistrzami [Janusz 2013]. Podobnie było w wyborach z 2010 roku, podczas których 350 ich przedstawicieli zostało wybranych do rad gmin [Czwarty raport... 2013: 106]. Z kolei w wyborach z 2014 roku 43 przedstawicieli mniejszości narodowych i etnicznych zostało wójtami 
i burmistrzami, a 452 zasiada z ramienia komitetów wyborczych mniejszości i innych komitetów wyborczych, w radach miast i gmin. Najwięcej przedstawicieli mniejszości zasiada we władzach samorządów gminnych w województwach: opolskim, podlaskim, podkarpackim, pomorskim, śląskim i warmińsko-mazurskim. Największe sukcesy polityczne odnoszą przedstawiciele organizacji mniejszości niemieckiej w województwie opolskim i białoruskiej w podlaskim oraz grupy kaszubskiej (społeczności posługującej się językiem regionalnym) w pomorskim [Piąty raport... 2015: 121-122].

\section{Gminy z dodatkowymi nazwami miejscowości w językach mniejszości narodowych w Polsce w latach 2005-2015}

Na podstawie regulacji ustawy o mniejszościach (próg „20\%” osób należących do mniejszości na podstawie danych ze spisu z 2002 roku) rozwiązania dotyczące dodatkowego nazewnictwa w językach mniejszości można było wprowadzić w 51 gminach. Dotyczyło to następujących języków mniejszości: niemieckiego (w 28 gminach), białoruskiego (12) i litewskiego (1) oraz języka regionalnego, czyli kaszubskiego (w 10 gminach). Stanowiły one razem $2 \%$ możliwych „dwujęzycznych” gmin na ogólną ich liczbę w naszym kraju wynosząca w 2005 roku 2478 jednostek.

Pierwsze dwujęzyczne tablice $\mathrm{z}$ dodatkowymi nazwami, ustalonymi na podstawie ustawy o mniejszościach, pojawiły się na Kaszubach i stanęły w miejscowości Szymbark (Szimbark) w końcu lipcu 2008 roku (gmina Stężyca, powiat kartuski, województwo pomorskie, gdzie wpis do rejestru został dokonany w listopadzie 2007 roku). Pierwszą miejscowością, w której postawiono tablice $\mathrm{z}$ dodatkowymi nazwami niemieckimi była wieś Łubowice (Lubowitz) położona w gminie Rudnik (województwo śląskie, powiat raciborski). Mimo że gmina została wpisana do rejestru w kwietniu 2008 roku, to uroczystość odsłonięcia tablic odbyła się już na początku września tego roku3 ${ }^{3}$. Pierwszą zaś całą gminą z prawem do dodatkowych nazw miejscowości w języku niemieckim stała się gmina Radłów, która jako pierwsza w ogóle gmina w Polsce została wpisana do rejestru jeszcze 2006 roku (z 11 nazwami).

3 Gmina Rudnik jest także pierwszą gminą, w której wprowadzono dodatkowe nazwy w języku mniejszości, mimo że mniejszość niemiecka stanowi w niej mniej niż 20\% mieszkańców gminy (13,4\% według spisu z 2002 roku). Jej podstawą były konsultacje społeczne przeprowadzone w jednej miejscowości - Łubowicach, która jest miejscem urodzin jednego z najwybitniejszych niemieckich poetów epoki romantyzmu Józefa von Eichendorffa (1788-1857). Z tego powodu odwiedza ją wielu Niemców; działa też tutaj Górnośląskie Centrum Kultury i Spotkań, które nosi jego imię. 
Na koniec 2015 roku ustalono łącznie 1211 dodatkowych nazw miejscowości w językach mniejszości narodowych i regionalnym w 58 gminach, w tym w 31 gminach - 359 nazw niemieckich, w 23 gminach - 786 kaszubskich, w jednej gminie - 30 litewskich, w jednej gminie - 27 białoruskich oraz $\mathrm{w}$ dwóch gminach -9 łemkowskich (tabela 1). Stanowi to drobny odsetek - 1,1\% wszystkich uznanych oficjalnie nazw miejscowości w Polsce (zgodnie $\mathrm{z}$ obowiązującym wykazem urzędowych nazw miejscowości i ich części z 2012 roku mamy w kraju 103225 nazw miejscowości oraz ich części).

Tabela 1. Wprowadzanie dodatkowych w nazw miejscowości w językach mniejszości i języku regionalnym w Polsce w latach 2006-2015*

\begin{tabular}{|c|r|r|r|r|r|r|}
\hline \multirow{2}{*}{ Rok } & \multicolumn{6}{|c|}{ Liczba gmin i dodatkowych nazw miejscowości (w nawiasie) w następujących językach } \\
\cline { 2 - 7 } & białoruski & litewski & lemkowski & niemiecki & kaszubski & razem \\
\hline 2006 & - & - & - & $1(12)$ & - & $1(12)$ \\
\hline 2007 & - & - & - & $1(14)$ & $2(86)$ & $3(100)$ \\
\hline 2008 & - & $1(30)$ & $1(1)$ & $13(150)$ & - & $15(181)$ \\
\hline 2009 & - & - & - & $4(53)$ & $2(88)$ & $6(141)$ \\
\hline 2010 & - & - & - & $5(58)$ & $3(83)$ & $8(141)$ \\
\hline 2011 & $1(27)$ & - & $1(8)$ & $3(37)$ & $4(140)$ & $9(212)$ \\
\hline 2012 & - & - & - & $1(12)$ & - & $1(12)$ \\
\hline 2013 & - & - & - & $1(7)$ & $7(279)$ & $8(286)$ \\
\hline 2014 & - & - & - & $2(16)$ & $3(68)$ & $5(84)$ \\
\hline 2015 & - & - & - & - & $2(42)$ & $2(42)$ \\
\hline Razem & $1(27)$ & $1(30)$ & $2(9)$ & $31(359)$ & $23(786)$ & $58(1211)$ \\
\hline
\end{tabular}

* Rok oznacza wpisanie gminy do rejestru gmin, a nie samo postawienie tablic, które było zazwyczaj późniejsze.

Źródło: opracowanie własne na podstawie „Rejestru Gmin, na których obszarze używane są nazwy w języku mniejszości” (www.mac.gov.pl/mniejszosci-i-wyznania, [28.12.2015].

Z tabeli 1 wynika, że dominują dodatkowe nazwy miejscowości w dwóch językach mniejszościowych, niemieckim oraz kaszubskim. Dostrzec można także różnicę między nimi polegająca na większej liczbie gmin i mniejszej liczbie dodatkowych nazw w wypadku gmin z językiem niemieckim, a mniejszą liczbę gmin (o jedną trzecią) i prawie dwa razy większą liczbę nazw w gminach z językiem kaszubskim. Mamy także po jednej gminie $\mathrm{z}$ dodatkowymi nazwami w języku białoruskim oraz litewskim, zaś w wypadku języka łemkowskiego jedna dodatkowa nazwa dotyczy 
jednej miejscowości na terenie gminy Gorlice (miejscowości Bielanka), a pozostałe 8 dodatkowych nazw miejscowości znajduje się już na terenie gminy Uście Gorlickie.

Do tej pory nie ustalono na podstawie ustawy o mniejszościach żadnej dodatkowej nazwy w języku mniejszości dla obiektu fizjograficznego, ani też formalnie nie wprowadzono dodatkowych nazw ulic i placów (choć takie nazwy, głównie w języku kaszubskim, są obecne w niektórych miejscowościach).

Z perspektywy czasowej 2005-2015 widać, że gminy z dodatkowymi nazwami $\mathrm{w}$ języku niemieckim były początkowo liderami wprowadzania dwujęzyczności. Momentem przełomowym stał się dla nich 2008 rok, w którym aż 13 gmin (z 150 nazwami) zostało wpisanych do rejestru z uprawnieniami do dodatkowych nazw (wcześniej większość z nich, choć nie wszystkie, uzyskały prawo do stosowania języka niemieckiego jako pomocniczego). W wypadku dodatkowych nazw w języku kaszubskim takim momentem przełomowym stał się z kolei 2013 rok, kiedy do rejestru zostało wpisanych 7 gmin z 279 dodatkowymi nazwami w tym języku.

Odwołując się do danych spisowych z 2002 roku, będących do momentu ogłoszenia wyników spisu z 2011 roku (co nastąpiło dopiero w końcu 2013) podstawą do wszczęcia procedury o dodatkowych nazwach, możemy zauważyć interesująca sytuację. W 2015 roku liczba dwujęzycznych gmin jest wyższa niż to oczekiwano w 2005 roku (58 wobec 51 gmin). Oceniając to z perspektywy poszczególnych języków mamy następująca sytuację: w przypadku 31 gmin z dodatkowymi nazwami miejscowości w języku niemieckim prawie wszystkie gminy (27 na 28 gmin), które przekraczały próg mniejszościowy na podstawie spisu z 2002 roku wprowadziły dodatkowe nazwy z wyjątkiem jednej gminy miejskiej Olesno (język niemiecki). Dodatkowo w trzech gminach wykorzystano procedurę konsultacji społecznych (gminy Rudnik, Gogolin oraz Pawłowiczki), a wprowadzenie dodatkowych nazw w gminie Popielów (wpis do rejestru w 2014) nastąpiło na podstawie wyników spisu z 2011 roku.

W wypadku 23 gmin z dodatkowymi nazwami miejscowości w języku kaszubskim w prawie wszystkich 10 gminach przekraczających próg mniejszościowych w 2002 roku zostały wprowadzone dodatkowe nazwy miejscowości w języku kaszubskim z wyjątkiem gminy wiejskiej Puck (gmina Przodkowo przekraczająca próg mniejszościowy zarówno w 2002 i 2011 roku wprowadziła dodatkowe nazwy dopiero w 2015). W 9 gminach wprowadzono nazwy na podstawie konsultacji społecznych - Bytowie, Kartuzach, Brusach, Kościerzynie - w gminie wiejskiej oraz miejskiej, Lipusz 
(choć według spisu z 2011 przekroczyła próg mniejszościowy - 39,9\%) oraz Wejherowie (gmina wiejska), Karsinie i Tuchomii. Pozostałe 5 gmin wykorzystały wyniki spisu z 2011 w zakresie osób posługujących się językiem regionalnym (Żukowo, Dziemiany, Lipnica, Czarna Dąbrówka, Luzino). W wypadku języka białoruskiego tylko 1 gmina (gmina Orle) zdecydowała się na wprowadzenie dodatkowych nazw na 12 gmin spełniających warunek progu mniejszościowego na podstawie danych ze spisu z 2002 roku. Z kolei dodatkowe nazwy w języku litewskim zostały wprowadzone w jednej gminie (na jedną możliwą według danych spisowych z 2002, jak i według danych z 2011). W wypadku łemkowskiego w dwóch gminach wprowadzenie dodatkowych nazw nastąpiło w drodze konsultacji społecznych. Ten krótki przegląd ukazuje nam znaczenie danych spisowych oraz niezależną od nich rolę konsultacji społecznych prowadzących do ustalenia dodatkowych nazw w językach mniejszości.

Najwięcej gmin $\mathrm{z}$ nazwami miejscowości w języku niemieckim pochodzi z województwa opolskiego (28) oraz trzy z województwa śląskiego, przylegające do województwa opolskiego. Najwięcej z nich znajduje się w powiatach opolskim (aż 9, tworząc rodzaj okręgu wokół miasta Opole), strzeleckim (5), kędzierzyńsko-kozielskim (5), oleskim (2) i raciborskim (2). Dodatkowe nazwy niemieckie otrzymało także 9 miast: Leśnica (pierwsze miasto $\mathrm{w}$ Polsce $\mathrm{z}$ dodatkową nazwą w języku niemieckim), Dobrodzień, Kolonowskie, Ujazd, Biała, Głogówek, Prószków (wszystkie w województwie opolskim) oraz Krzanowice i Sośnicowice (w województwie śląskim). Żadne miasto powiatowe w województwie opolskim nie uzyskało do tej pory dodatkowej nazwy w języku niemieckim (choć wymóg przekroczenia progu 20\% osób według spisu z 2002 roku spełniło Olesno). Z kolei wszystkie gminy z nazwami w języku kaszubskim pochodzą z województwa pomorskiego, a najwięcej $\mathrm{z}$ nich znajduje się $\mathrm{w}$ powiatach kartuskim (8), kościerskim (5) oraz bytowskim (4) i wejherowskim (4), tworząc zwarty o kształcie trapeza obszar w ramach tego regionu. Dodatkowe nazwy kaszubskie otrzymało także 5 miast: Bytów (pierwsze miasto powiatowe zarówno $\mathrm{z}$ dodatkową nazwą $\mathrm{w}$ języku mniejszości oraz w języku kaszubskim), Kartuzy i Kościerzyna (również miasta powiatowe) oraz Brusy i Żukowo.

Gminy z dodatkowymi nazwami w językach mniejszości mają w przeważającej większości status gmin wiejskich, to znaczy takich, które na swoim terytorium nie mają miast (43 gminy, w tym $21 \mathrm{z}$ nazwami niemieckim i $18 \mathrm{z}$ nazwami kaszubskimi) oraz miejsko-wiejskich, to znaczy takich, w skład których wchodzi miasto oraz wsie (14, w tym $10 \mathrm{z}$ nazwami niemieckimi, a $4 \mathrm{z}$ nazwami kaszubskimi). Tylko jedna gmina posiada 
status gminy miejskiej, którą jest Kościerzyna-miasto z dodatkową nazwą w języku kaszubskim.

$\mathrm{Na}$ terenie 58 gmin $\mathrm{z}$ dodatkowymi nazwami miejscowości w językach mniejszości mieszka prawie 600 tys. osób (579161 mieszkańców), a przeciętna liczba mieszkańców takiej jednostki wynosi prawie 10 tys. mieszkańców (9 985), przy czym przeciętna liczba mieszkańców gmin z dodatkowymi nazwami w języku kaszubskim (12746) jest większa niż gmin z nazwami w języku niemieckim (8235), co wynika z wpływu dużych liczebnie gmin miejsko-wiejskich na terenie Kaszub. Najmniejszą liczebnie gminą z dodatkowymi nazwami miejscowości jest gmina Orle $\mathrm{z}$ nazwami w języku białoruskim (3055 mieszkańców), a największą liczebnie gminą są Kartuzy z dodatkowymi nazwami kaszubskimi (32631 mieszkańców).

Dodajmy, że w dużej części gmin z dodatkowymi nazwami miejscowości w językach mniejszości mamy także języki mniejszości jako pomocnicze do pracy urzędów, wprowadzane na podstawie jedynie wymogu ustawowego przekroczenia „20\%” progu mniejszościowego. Na koniec 2015 roku mieliśmy wpisane do niego 33 gminy (a więc zdecydowanie mniej niż $\mathrm{z}$ dodatkowymi nazwami), w tym 5 gmin $\mathrm{z}$ językiem białoruskim, 22 gminy $\mathrm{z}$ językiem niemieckim (wszystkie $\mathrm{z}$ województwa opolskiego), 5 gmin $\mathrm{z}$ językiem kaszubskim oraz jedną z językiem litewskim. Decydujące znaczenie miało przekroczenie progu 20\% (stąd gminy, w których wprowadzenie dodatkowych nazw odbyło się na podstawie konsultacji społecznych nie miały na to szans) oraz społeczne przekonania na temat używalności języków mniejszości. W sześciu gminach, w których wprowadzono niemiecki jako język pomocniczy (Bierawa, Chrząstowice, Dobrodzień, Dobrzeń Wielki, Izbicko i Komprachcice), mniejszość według danych ze spisu z 2011 roku stanowi już mniej niż 20\% mieszkańców.

\section{Problemy instytucjonalne wprowadzania dodatkowych nazw miejscowości w językach mniejszości narodowych}

Wprowadzanie dodatkowych nazw miejscowości w językach mniejszości budziło zarówno problemy instytucjonalne (proceduralne i prawnoadministracyjne), jak i społeczne, związane z ich odbiorem i akceptacją. Rozpoczniemy od tych pierwszych. Dotyczyły one następujących kwestii: spełnienia wymogu przekroczenia „20\%” progu mniejszościowego według danych z ostatniego spisu powszechnego ludności, konieczności przeprowadzania konsultacji społecznych dotyczących nazw (i potraktowania ich jako odrębnej drogi ich wprowadzenia), charakteru samych nazw (ich 
historyczności oraz poprawności językowej) i wyglądu tablic z dodatkowymi nazwami, dążenie do ich rozszerzania na inne obiekty (takie jak ulice, stacje kolejowe i inne) oraz sposobu ich finansowania.

Zacznijmy od kwestii przekroczenia „progu mniejszościowego” na podstawie danych spisowych. Ostatni spis powszechny ludności przeprowadzony w naszym kraju w 2011 roku oraz jego wyniki dotyczące deklaracji narodowych i językowych przyniosły zmiany wobec wyników spisu z 2002 roku, który był przez długi czas główną podstawą o starania się o dodatkowe nazwy. Według jego danych nadal mamy 51 gmin spełniających warunek przekroczenia „20\% progu” mniejszościowego, ale zmienił się ich skład. Obecnie możliwość wprowadzenia dwujęzyczności dotyczy następujących języków mniejszości: niemieckiego (22 gmin, w tym 3 nowe gminy), białoruskiego (9) i litewskiego (to jest nadal ta sama gmina) oraz języka regionalnego, czyli kaszubskiego (19). W wypadku języka niemieckiego 20 gmin nadal przekracza próg 20\% (na 28 gmin w 2002 ), osiem zmniejszyło swój udział ludności niemieckiej poniżej tego wymagania, ale przybyły 3 dodatkowe nowe gminy: Popielów (województwo opolskie) oraz gminy Rudnik i Piotrowice Wielkie (województwo śląskie, powiat raciborski). Z kolei wszystkie gminy kaszubskie z 2002 roku utrzymały swoje progi mniejszościowe (łącznie z gminą wiejską Puck), ale jednocześnie doszło 9 nowych gmin. W wypadku języka białoruskiego wyniki spisu z 2011 roku zmniejszyły liczbę z 12 gmin do 9 (spadek deklaracji białoruskich poniżej 20\% miał miejsce w gminie miejskiej Bielsk Podlaski oraz gminach Czeremcha i Gródek). Spis z 2011 roku nie zmienił sytuacji języka litewskiego (nadal to jest gmina Puńsk) oraz języka łemkowskiego (w żadnej gminie mieszkańcy deklarujący przynależność łemkowską nie przekroczyli progu 20\%).

Zmienność wyników spisowych zrodziła dyskusję na temat, czy gmina, w której liczba mieszkańców należących do mniejszości ustalona w wyniku kolejnego spisu powszechnego ludności zmniejszyła się poniżej 20\% ogólnej liczby mieszkańców gminy, może zostać wykreślona z rejestru gmin i wycofać dodatkowe nazwy. Wywołało to dyskusję polityczną i próby takiej nowelizacji ustawy o mniejszościach, która umożliwiałaby wykreślenie takich gmin z rejestru i likwidację dodatkowych nazw (wniosek Solidarnej Polski z 2012 roku). Próba ta została odrzucona, a oficjalna interpretacja departamentu wyznań i mniejszości była jednoznaczna - stanowiła ona, że świetle obowiązujących regulacji nie ma możliwości wykreślenia takiej gminy z rejestru (taka opinia znalazła się na oficjalnej stronie internetowej ministerstwa). 
Obok zmienności wyników spisów ludności dużym wyzwaniem stało się porównywanie wyników spisowych z aktualną liczbą mieszkańców gminy. Procedura zobowiązuje rady gmin, aby we wniosku o zapis tej gminy w rejestrze podawała dane o liczbie mieszkańców należących do mniejszości oraz aktualną liczbę mieszkańców gminy (która jest zazwyczaj późniejsza niż moment przeprowadzenia spisu), co stanowi podstawę do przekroczenia progu mniejszościowego. Pojawiają się czasami problemy, jak na przykład w gminie Popielów w województwie opolskim. Przekroczyła ona nieznacznie granicę 20\% mieszkańców należących do mniejszości niemieckiej według spisu z 2002 roku, ale ze względu na zmniejszenie się ogólnej liczby mieszkańców gminy nie spełniała już wymogu przekroczenia progu „20\%” [Janusz 2011: 648-649]. Gmina ta wypełniała ten warunek dopiero niedawno i została ostatecznie wpisana do rejestru we wrześniu 2014 roku.

Innym problemem stał się spór o konsultacje społeczne w sprawie o dodatkowe nazwy. Na początku całego procesu wprowadzania dodatkowych nazw (lata 2005-2007) barierą stał się spór o interpretację zapisu ustawy o mniejszościach, który stanowił, że wprowadzenie dodatkowych nazw winno być każdorazowo poprzedzone konsultacjami społecznymi, nawet wtedy, gdy gmina spełnia warunek przekroczenia 20\% mieszkańców należących do mniejszości. Ówczesne władze Ministerstwa Spraw Wewnętrznych „obstawały” przy warunku obowiązkowości konsultacji. Zrodziło to napięcia $w$ ich relacjach $z$ organizacjami mniejszości i opóźniło wprowadzanie dodatkowych nazw miejscowości (dotyczyło to szczególnie gmin z województwa opolskiego). Ministerstwo wycofało się następnie ze swojej interpretacji uznając, że ustawa o mniejszościach przewiduje dwie niezależne od siebie możliwości złożenia wniosku rady gminy o dodatkową nazwę miejscowości w języku mniejszości - pierwszą, która jest związana z przekroczeniem progu 20\% (i wtedy nie są potrzebe konsultacje społeczne) oraz drugą, odnoszoną do tych gmin, w których liczba mieszkańców gminy należących do mniejszości jest mniejsza niż wymagane $20 \%$. W przypadku takich gmin przeprowadzenie i omówienie wyników konsultacji społecznych jest koniecznym elementem wniosku o dodatkowe nazwy. W omawianym okresie 2005-2015 w 14 gminach wprowadzono dodatkowe nazwy miejscowości na podstawie konsultacji lokalnych (nazwy w języku niemieckim - w 3 gminach, w kaszubskim w 9 i w łemkowskim w 2).

Inną kwestią stała się z kolei frekwencja mieszkańców w ramach konsultacji. Nie była ona wysoka, ale w prawie w każdym przypadku opowiadano się za wprowadzeniem dodatkowych nazw w językach mniejszości. Wiązało się to między innymi z dużą mobilizacją poszczegól- 
nych mniejszości. Konsultacje wzbudzały czasami duże emocje lokalne, gdy dodatkowa nazwa przechodziła niewielką większością głosów (przykładem może być już wspominana nazwa miejscowości Bielanka w języku łemkowskim). Szczególnym wyzwaniem stały się konsultacje w gminach (zwłaszcza miejskich) oraz miastach powiatowych, w których mniejszość stanowiła poniżej $20 \%$ mieszkańców. Stało się to poważnym problemem w województwie opolskim, gdzie rady gmin były im zazwyczaj przeciwne (w województwie opolskim miało to miejsce między innymi w Krapkowicach, Strzelcach Opolskich i Oleśnie). Odwrotnie sytuacja ta przedstawiała się w przypadku nazw kaszubskich i gmin województwa pomorskiego. Tam przeprowadzenie takich konsultacji nie sprawiało problemów oraz nie budziło prawie w ogóle negatywnych emocji. Przykładem może być tutaj gmina Bytów, w której dzięki konsultacjom społecznym wprowadzono dodatkowe nazwy miejscowości w języku kaszubskim, mimo że odsetek osób posługujących się tym językiem wyniósł według spisu z 2002 roku tylko 0,3\% (71 osób).

Nie było natomiast prawie żadnych trudności przy weryfikacji wniosków gmin o dodatkowe nazwy przez Komisję Nazw Miejscowości i Obiektów Fizjograficznych. Przegląd wydawanych przez nią opinii wskazuje, że obok kryterium historycznego (proponowane nazwy nie mogły nawiązywać do okresu 1933-1945), najpoważniejszym problemem była odpowiednia pisownia nazw poszczególnych miejscowości zgodnych z regułami danego języka (dotyczyło to zwłaszcza nazw w języku kaszubskim i białoruskim). Z perspektywy historyczności nazw jedynym wyjątkiem okazała się miejscowość Góra św. Anny (gmina Leśnica, powiat strzelecki, województwo opolskie), w której wprowadzono nazwę dodatkową Sankt Annaberg mimo że została ona oficjalnie uznana w 1934 roku. Rada gminy udowodniła, że mimo wcześniejszej nazwy w języku niemieckim Annaberg, w dokumentach kościelnych już w XIX wieku nazwa Sankt Annaberg była już stosowana. Została ona zaakceptowana przez Komisję Nazw Miejscowości oraz Ministerstwo Spraw Wewnętrznych.

Podobnie wygląd tablic informacyjnych oraz krój liter nazwy polskiej oraz dodatkowej nie rodził większych problemów. Ustawa o mniejszościach, jak i specjalne rozporządzenie ministra infrastruktury z 2005 roku odwoływały się do równorzędności wielkości czcionek w obu rodzajach nazw [Rozporządzenie... 2005]. Powinny one znajdować się na jednej tablicy, być wyśrodkowane, z tym, że nazwa „mniejszościowa” winna być pod nazwą w języku polskim. Wygląd tablic symbolicznie więc wizualizował relacje „większość - mniejszość, czego są świadomi członkowie mniejszości. 
Mimo jednoznaczności przepisu niektóre gminy, szczególnie na początku procesu wprowadzania dodatkowych nazw, umieszczały nazwy miejscowości na dwóch odrębnych tablicach (między innymi w Łubowicach i gminie Cisek w województwie opolskim).

Podobnie nie budziły problemów zagadnienia procedur przetargowych i kosztów wymiany tablic. Zgodnie z ustawą o mniejszościach nakłady na ich wymianę są pokrywane $\mathrm{z}$ budżetu państwa. Ministerstwo zawiera każdorazowo $\mathrm{z}$ gminą zapisaną $\mathrm{w}$ rejestrze umowę o sfinansowaniu takiej wymiany. Wymaga, aby wykonawca tablic był wybierany w trybie prawa o zamówieniach publicznych; uważnie przygląda się także stronie formalnej (zwłaszcza prawidłowemu opisowi faktur) i terminowości rozliczeń finansowych (w tym także terminowi zwrotu niewykorzystanej sumy dotacji).

Wyzwaniem stały się natomiast próby rozszerzenia dodatkowego nazewnictwa miejscowości w językach mniejszości poza tablice informacyjne z nazwami miejscowości. Ustawa o mniejszościach daje możliwości umieszczania dodatkowych nazw na wszystkich znakach i tablicach, na których umieszczone są urzędowe nazwy miejscowości (jak i obiektów fizjograficznych i nazw ulic) na terenie całej gminy. Dotyczy to więc między innymi rozszerzenia dodatkowego nazewnictwa na drogowe tablice kierunkowe (drogowskazy) oraz także na nazwy miejscowości na stacjach kolejowych. Próby ich wprowadzenia wzbudziły szczególnie duże emocje w gminie Chrząstowice (województwo opolskie), gdzie spotkały się one z protestem politycznym (pojawiły się w 2012 roku później zostały zdjęte z powodu remontu szlaku kolejowego i stacji), a teraz ponownie zawisły (listopad 2015). Ostatnio (grudzień 2015) w Kartuzach (województwo pomorskie) rozpoczęła się debata o możliwości wprowadzenia dodatkowej nazwy stacji kolejowej w języku kaszubskim.

Obecnie we wnioskach o dodatkowe nazwy pojawia się oczekiwanie wprowadzenia dodatkowych nazw nie tylko na tablicach przed wjazdami do miejscowości, ale także na tablicach kierunkowych. Przykładem może być gmina Orla (nazwy białoruskiej) oraz gminy kaszubskie. Do tej pory nie zostały złożone wnioski o dodatkowe nazwy ulic w języku mniejszości (wynika to między innymi z częstych ich zmian oraz kosztów wymiany, które już obciążają budżet gminy) oraz nazw topograficznych („obiektów fizjograficznych").

Omawiane kwestie proceduralne związane $\mathrm{z}$ dodatkowymi nazwami dotyczyły głównych aktorów całego procesu - rad gmin oraz ich wójtów i burmistrzów oraz całej administracji, zwłaszcza ministerstwa. Były one rzadko przedmiotem dyskusji publicznych i raczej niewidoczne. Ale zapo- 
wiedzi ich postawienia oraz ich pojawienie się wywoływało już dyskusje społeczne o ich potrzebie.

\section{Dodatkowe nazwy miejscowości w językach mniejszości narodowych a etniczne „flagowania” rzeczywistości}

Gminy oraz społeczności lokalne, w których wprowadzono dodatkowe nazwy miejscowości w językach mniejszości były zróżnicowane etnicznie i językowo. Ważną ich cechą była „autochtoniczność” mieszkańców, przez co były one społecznie silnie zintegrowane, świadome swoich tradycji historycznych, w tym także historycznej ewolucji nazw swoich miejscowości. Po 1990 roku powstało i rozwinęło się na ich terenie szkolnictwo w językach mniejszości, były prowadzone nabożeństwa w językach mniejszościowych, a lokalne organizacje lub oddziały stowarzyszeń mniejszości były aktywne i widoczne. One także wybierały i popierały swoich kandydatów do rad gmin oraz na stanowiska wójtów i burmistrzów. W tych właśnie społecznościach elementy zróżnicowania etnicznego i kulturowego stały się widoczne w sferze publicznej, a grupa mniejszościowa w dużym stopniu była zorganizowana. Można powiedzieć, że omawiane „dwujęzyczne” gminy były lokalnymi wersjami społeczności wielokulturowych, które cechuje, zdaniem Andrzeja Sadowskiego, „wysoki stopień instytucjonalizacji zróżnicowania kulturowego" [Sadowski 2011: 58]. Były one więc społecznie "gotowe” na dodatkowe nazwy, a ustawa o mniejszościach stała się długo oczekiwaną "furtką" prawną umożliwiającą ich wprowadzenie.

Z perspektywy grupy mniejszościowej tablice dwujęzyczne mogą być analizowane jako ważne „instytucje tożsamościowe”, które przywracają i „terytorializują” ojczyznę lokalną, własny „stary” teren zamieszkania, podobnie jak to ma miejsce w wypadku map, wyobrażeń krajobrazu, pomników i innych rodzajów upamiętnień. Ten proces „etnicyzacji” i „unaradawiania” przestrzeni miał konstruować i podtrzymywać przeszłe, teraźniejsze oraz przyszłe wyobrażenie o miejscu swojej grupy na tym terenie w taki sposób, aby dodatkowe nazwy były postrzegane przez mieszkańców jako „naturalne” i zawsze obecne. Stanowiły one dla jej przedstawicieli „dobro symboliczne”, związane z genealogią poszczególnych rodzin oraz historią indywidualnych biografii jej członków. Określały one ich związek i identyfikację z miejscem zamieszkania, wyrażającą poczucie przynależności „lokalnej”, ujawniającej się w potrzebie zaznaczenia własnego miejsca poprzez odniesienie się do przeszłości i podtrzymania jej ciągłości. Miały one ułatwić odpowiedź na pytania, skąd jesteśmy oraz kim jesteśmy w sensie kulturowo-historycznym? 
Wprowadzenie tablic dwujęzycznych było często dużym wydarzeniem lokalnym, związanym z uroczystościami, a także i nabożeństwem religijnym.

Pojawienie się tablic z dodatkowymi nazwami było traktowane również w kategoriach „etnicznych” sprzyjających oczekiwaniom grupy mniejszościowej i ocenianym poprzez pryzmat realizacji ich „etnicznych” oczekiwań. Nie były one traktowane jako wyraz realizacji europejskich standardów ochrony mniejszości lub wypełnienia możliwości stwarzanych przez ustawę o mniejszościach, lecz jako zmiana w lokalnej „domenie symbolicznej”. Nazwy oznaczały bowiem emancypację mniejszości narodowej na poziomie lokalnym, jej przesunięcie z pozycji marginesowej jako grupy mniejszościowej do statusu widocznego publicznie. Ich pojawieniu towarzyszyły także emocjonalne dyskusje $\mathrm{w}$ środkach masowego przekazu (głównie regionalnych), jak i na forach internetowych, które wybuchały dopiero po ich ustawieniu w danych miejscowościach. Miały one w dużej części wydźwięk negatywny, sprzeciwiający się ich obecności i podkreślający polski, tak państwowy, jak i kulturowy charakter tego regionu. Raczej nieliczne wypowiedzi podkreślały akceptację wynikającą z ich tradycyjnego rodowodu oraz przejawiania szacunku dla społeczności mniejszościowej. Zdaniem Moniki Choroś, specjalistki od tych zagadnień, na Opolszczyźnie stawienie dwujęzycznych tablic było bardziej „związane z emocjonalną, uczuciową stroną życia niż z pragmatyczną. Stanowią one bowiem widoczny znak, może nawet element «polityki pamięci»" [Choroś 2012: 141].

Dodatkowe nazwy miejscowości w językach mniejszości budziły także negatywne zjawiska wyrażające się w częstych incydentach polegających na ich zamalowywaniu. W sierpniu 2011 roku stał się głośny incydent zamalowywania tablic polsko-litewskich w Puńsku, który spotkał się z potępieniem oraz działaniem prokuratury, a także potępiającymi wystąpieniami ministrów sprawiedliwości i spraw zagranicznych Polski oraz Litwy. Przedstawiciele mniejszości niemieckiej wystosowali wówczas list otwarty do władz państwa wskazujący na liczne akty wandalizmu również wobec tablic polsko-niemieckich oraz bezczynność organów administracji, co mogło rodzić, zdaniem liderów tej grupy, wrażenie stosowania różnych standardów w traktowaniu poszczególnych grup mniejszościowych w Polsce. Ostatnie takie sytuacje miały miejsce w czerwcu 2014 roku w Puńsku (nazwy litewskie) oraz w województwie opolskim i śląskim w lipcu 2013 i w lutym 2014 roku (nazwy w języku niemieckim). Obecnie jednak obserwuje się spadek liczby tych incydentów. Mimo wysokiej emocjonalnej temperatury dyskusje dotyczące dwujęzyczności nie prowadziły do powstania lokalnych konfliktów etnicznych. 
Porównanie wprowadzania dodatkowych nazw oraz ich codziennego funkcjonowania wskazuje także na różnice społeczne w zależności od grupy mniejszościowej i języka. Rozpoczniemy od gmin z nazwami miejscowości w języku niemieckim. Większość rozmówców docenia ich wprowadzenie, które, ich zdaniem, są przejawem szacunku dla niemieckiej przeszłości tego regionu oraz obecności jej kultury (podkreśla się tu zwłaszcza „historyczną” rolę tych nazw), a także akceptacją samej mniejszości niemieckiej działającej na tym terenie. Przedstawiciele władz tych gmin oraz liderzy mniejszości niemieckiej zwracali uwagę, że ustawa o mniejszościach dała im prawo do postawienia „u siebie” dwujęzycznych tablic. Podkreślali ich „europejskość, gdyż są zgodne nie tylko z europejskimi standardami ochrony mniejszości, ale i także z doświadczeniami dwujęzycznymi występującymi w Niemczech (przykład Serbołużyczan), jak i w innych krajach europejskich [Trosiak 2013: 160-161]. W wywiadach z mieszkańcami terenów dwujęzycznych można było także spotkać głosy im przeciwne (wypowiadane nawet ze strony rodowitych mieszkańców gminy), mówiące o tym, że dodatkowe nazwy są niepotrzebne tutaj i nie ma żadnego uzasadnienia dla ich wprowadzenia. Obawiano się wytworzenia napięć i podziałów lokalnych, o czym świadczyły częste przypadki ich zamalowywania na tablicach drogowych. Było to wyrazem obecności, w ich opinii, „narodowego” dyskursu o obecności dodatkowych nazw miejscowości w języku niemieckim.

$\mathrm{Z}$ kolei wprowadzenie dodatkowych nazw miejscowości w języku kaszubskim przeszło praktycznie bezkonfliktowo oraz nie wywoływało podziałów w ramach społeczności lokalnej. Wręcz przeciwnie, nazwy te traktowano jako naturalny „kapitał symboliczny” mieszkańców i regionu, a także jako element strategii mającej przyciągnąć tutaj jak najwięcej turystów. Zdaniem rozmówców, publiczna widoczność tych dodatkowych nazw wskazuje przede wszystkim na to, kto pełni tutaj rolę "gospodarza”. Poświadcza również poczucie dumy z wysokiego statusu języka (i kultury) kaszubskiego, który stał się „równy” językowi polskiemu (mimo problemów związanych ze standaryzacją językową nazw, często odmiennych od nazw obecnych w lokalnych odmianach mowy kaszubskiej). Podkreśla się rolę konsultacji społecznych jako sposobu uzyskiwania zgody na nazwy oraz rolę Zrzeszenia Kaszubsko-Pomorskiego jako ich promotora [Grzędzicki, Lemańczyk 2010: 29].

W wypadku gminy Puńsk, jedynej w Polsce gminy z dodatkowymi nazwami w języku litewskim, ich postawienie było czymś naturalnym i oczekiwanym, obecnym w od dawna w sferze nieformalnej. Nazwy miały zaznaczyć rolę pozycji gospodarzy i obecność języka i „litewskości” na 
tym terenie (język litewski stanowi najważniejszy wyznacznik tożsamości mniejszości litewskiej), [Wójcikowska 2013: 2]. Wprowadzenie nazw przeszło praktycznie bez żadnych problemów. Sprzyjały temu silne poczucie odrębności narodowej, zwartość terytorialna oraz mobilizacja całej grupy, a jednocześnie bezpośrednia bliskość państwa litewskiego [Barwiński 2014; Wójcikowska 2014: 80]. Jednocześnie nazwy te stały się przedmiotem „bi-lateryzacji” w państwowych relacjach polsko-litewskich, a zwłaszcza brakiem takich rozwiązań dla polskiej grupy na Litwie. Zdaniem rozmówcy opinie na ten temat negatywnie wpływają na sytuację mniejszości litewskiej na całej Suwalszczyźnie oraz tworzyły podstawę do akcji zamalowywania dwujęzycznych polsko-litewskich tablic w gminie Puńsk w sierpniu 2011 oraz w czerwca 2013 roku.

W przypadku dwóch gmin $\mathrm{z}$ dodatkowymi nazwami w języku łemkowskim zwraca uwagę z jednej strony przypadek miejscowości Bielanka. W jej wypadku mieliśmy do czynienia z ostrym i długotrwały sporem o dodatkową nazwę (została ona wprowadzona na podstawie konsultacji społecznych przewagą tylko jednego głosu), a postawione tablice były często zamalowywane i niszczone. Spór o nią nabrał także charakteru etniczno-religijnego [Pasieka 2013: 152]. Z drugiej strony w sąsiedniej gminie Uście Gorlickie dodatkowe nazwy w języku łemkowskim wprowadzono podobnie na podstawie konsultacji społecznych, ale były one poprzedzone serią rozmów i licznymi spotkaniami władz gminy z jej mieszkańcami. Nie wzbudzają one negatywnych emocji, świadczą o przeszłości kulturowej tej ziemi oraz obecności na jej terenie grupy łemkowskiej.

Z kolei obecność tylko jednej gminy z dodatkowymi nazwami w języku białoruskim (a przypomnijmy, że w świetle danych spisowych z 2002 roku aż 12 gmin miało prawo do takich dodatkowych nazw) wynika $\mathrm{z}$ deklarowanych obaw przed możliwymi konfliktami narodowościowymi na tym terenie, a także podziałami pokoleniowymi w mniejszości białoruskiej - między bardziej „ostrożnym” narodowo starszym pokoleniem a bardziej „otwartym” pod tym względem młodszym [Siegień-Matyjewicz 2011: 238-239]. Wyraża się także przekonanie, że dodatkowe nazwy nie są jeszcze konieczne [Vasilevich 2014: 9]. Problemem jest również pisownia i wymowa dodatkowych nazw, które są podawane w standardowym języku białoruskim, różniącym się od lokalnych odmian mówionego języka białoruskiego.

Wprowadzanie dodatkowych nazw w językach mniejszości narodowych wskazuje na rolę języka oraz zróżnicowania językowego w określaniu tożsamości etnicznej na poziomie lokalnym. Nazwy stały się zewnętrznymi 
znakami tożsamości etnicznej mniejszości ustalając „granice symboliczne" w społeczności lokalnej. Proces ich instytucjonalizacji nie był jednak prostym dostosowaniem regulacji prawnych. Zawsze był związany z historią danej grupy w regionie, jej językiem i kulturą, jak i pamięcią wzajemnych relacji polsko-mniejszościowych. Natomiast dyskusje na temat dwujęzyczności stanowiły odbicie głębszych i szerszych sporów o tożsamość regionu i zamieszkującej go ludności, a także jego tradycji historycznych.

\section{Zakończenie}

Przedstawiony $\mathrm{w}$ artykule wstępny i skrótowy opis wprowadzania dodatkowych nazw miejscowości w językach mniejszości wskazuje na zmianę sposobu publicznej prezentacji odrębnej tożsamości etnicznej przez grupy mniejszościowe. Odbywa się ono nie tylko przez działania służące podtrzymywaniu tradycyjnej kultury narodowej oraz umacnianiu granic wspólnotowych, lecz także przez wkraczanie w sferę publiczną i poszukiwanie nowych, wizualnych sposobów uwidocznienia swojej odrębności. Działania w tej dziedzinie mogą być potraktowane jako jeden ze sposobów afirmacji ich odrębności, które na poziomie gminy nabiera charakteru działania strategicznego, obejmującego całą społeczność lokalną [Herman 2014: 43]. Oznacza to także naruszenie dotychczasowej hierarchii władzy symbolicznej i konieczność tworzenia wspólnot wielokulturowych. Powstają więc pytania o sposób funkcjonowania zróżnicowanych kulturowo i językowo społeczności lokalnych, które starają się łączyć integrację społeczną $\mathrm{z}$ emancypacją granic etnicznych.

\section{Bibliografia}

Adamczyk A., Sakson A., Trosiak C. (red.), (2015), Między lękiem a nadzieją. Dziesięć lat funkcjonowania ustawy o mniejszościach narodowych i etnicznych oraz języku regionalnym (2005-2015), Poznań.

Alderman D. H. (2008), Place, Naming and the Interpretation of Cultural Landscapes, [w:] B. Graham, P. Howard (eds.), The Ashgate Research Companion to Heritage and Indentity, Farnham-Burlington.

Balzas L., Schwellnus G. (2014), Decoupled Empowerment: Minority Representation and the Implementation of Language Rights in Romania, "Journal on Ethnopolitics and Minority Issues in Europe", t. 13, nr 2, s. 104-131.

Barwiński M. (2014), Mniejszość litewska w Polsce. Studium przypadku gminy Puńsk, „Studia Obszarów Wiejskich”, t. 35, s. 137-153. 
Billig M. (2008), Banalny nacjonalizm, Kraków.

Blommaert J. (2013), Etnography, superdiversity and linguistic landscapes, Bristol-BuffaloToronto.

Bajor H. (1996), Mniejszości narodowe - nowe formy uczestnictwa w życiu III Rzeczypospolitej, [w:] H. Domański, A. Rychard (red.), Elementy nowego ładu, Warszawa.

CBOS (2015) Tożsamość narodowa Polaków oraz postrzeganie mniejszości narodowych $i$ etnicznych $w$ Polsce. Komunikat z badań, Warszawa.

Choroś M. (2012), Dwujęzyczne tablice z nazwami miejscowości na Opolszczyźnie: przejaw demokracji czy źródło nowych konfliktów?, „Przegląd Zachodni”, nr 1.

Czerny A. (2011), Teoria nazw geograficznych, „Prace Geograficzne”, nr 226.

Czwarty raport dotyczący sytuacji mniejszości narodowych i etnicznych oraz języka regionalnego w Rzeczypospolitej Polskiej (2013), Ministerstwo Administracji i Cyfryzacji, Warszawa.

Dołowy-Rybińska N. (2013), The Europe of Minorities: Cultural Landscape and Ethnic Boundaries, "Art Inquiry. Recherches sur les Arts", t. XV.

Donnan H., Wilson T. M. (2007), Granice tożsamości, narodu, państwa, Kraków.

Dziewierski M. (2008), Duchowość i etnosymbolika, „Przegląd Socjologii Jakościowej”, t. IV, nr 1.

Edensor T. (2004), Tożsamość narodowa, kultura popularna i życie codzienne, Kraków.

Ganowicz E. (2013), Niepartyjne formy ekspresji politycznej mniejszości narodowych, „Annales Universitatis Paedagogicae Cracoviensis Studia Politologica”, t. XI.

Godlewska E. (2014), Prawa językowe mniejszości narodowych - problem $w$ realizacji, [w:] A. Sakson (red.), Mniejszości narodowe i etniczne w Polsce i Europie. Aspekty polityczne i społeczne, Torun.

Grzędzicki Ł., Lemańczyk M. (2010), Raport. Wprowadzanie języka kaszubskiego w gminach województwa pomorskiego jako języka pomocniczego oraz dodatkowych tradycyjnych nazw miejscowości i obiektów fizjograficznych, Gdańsk.

Hałas E. (2004), Polityka symboliczna i pamięć zbiorowa. Zmiany nazw ulic po komunizmie, [w:] M. Marody (red.), Zmiana czy stagnacja?, Warszawa.

Handke K. (2009), Socjologia języka, Warszawa.

Herman A. (2014), Ukraińcy grekokatolicy i Polacy mariawici wśród Polaków rzymskich katolików. Lokalne zróżnicowania społeczne i mechanizmy jego utrzymywania w perspektywie porównawczej, „Studia Humanistyczne AGH”, t. 13, nr 2.

Janusz G. (2011), Ochrona praw mniejszości narodowych w Europie, Lublin.

Janusz G. (2013), Ekspertyza dotycząca udziału mniejszości narodowych i etnicznych w życiu politycznym Rzeczypospolitej Polskiej, Lublin.

Janusz G. (2015), Podmiotowa ochrona w ustawie $z$ dnia 6 stycznia 2005 roku o mniejszościach narodowych i etnicznych oraz o języku regionalnym, [w:] A. Adamczyk, A. Sakson, C. Trosiak (red.), Między lękiem a nadzieja. Dziesięć lat funkcjonowania ustawy o mniejszościach narodowych i etnicznych oraz języku regionalnym (2005-2015), Poznań. 
Kaltenberg-Kwiatkowska E. (2011), O oznaczaniu i naznaczaniu przestrzeni miasta, „Przegląd Socjologiczny", t. 60, nr 2/3.

Kamusella T. (2009), The Politics of Language and Nationalism in Modern Central Europe, New York.

Lamont M., Molnár V. (2002), The Study of Boundaries in the Social Sciences, "Annual Review of Sociology", nr 28.

Landry R., Bourhis R. Y. (1997), Linguistic Landscape and Ethnolinguistic Vitality: An Empirical Study, "Journal of Language and Social Psychology", t. 16, nr 1.

Marten H. F., Mensel L., Gorter D. (2012), Studying Minority Languages in the Linguistic Landscape, [w:] H. F. Marten, L. Mensel D. Gorter (red.), Minority Languages in the Linguistic Landscape, Basingstoke-New York.

Malloy T. H. (2005), National Minority Rights in Europe, New York.

Nijakowski L. M. (2007), Domeny symboliczne. Konflikty narodowe i etniczne w wymiarze symbolicznym, Warszawa.

Nijakowski L. M. (red.), (2014), Konferencja Europejskie i regionalne instrumenty ochrony języków zagrożonych Warszawa, 5 listopada 2013 r., Kancelaria Sejmu, Warszawa.

Pasieka A. (2013), Wielokulturowość po polsku. O polityce wielokulturowości jako mechanizmie umacniania polskości, „Kultura i Społeczeństwo”, nr 3.

Piąty raport dotyczący sytuacji mniejszości narodowych i etnicznych oraz języka regionalnego w Rzeczypospolitej Polskiej (2015), Ministerstwo Administracji i Cyfryzacji, Warszawa.

Plewko J. (2009) Mniejszości narodowe w wymiarze lokalnym, Lublin.

Rozporządzenie w sprawie umieszczania na znakach i tablicach dodatkowych nazw w językach mniejszości narodowych i etnicznych i języku regionalnym (2005), Dz. U. 157, poz. 1320.

Sadowski A. (2011), Społeczeństwo polskie - od zróżnicowanego kulturowo do wielokulturowego. Szanse i zagrożenia, [w:] A. Śliż, M. S. Szczepański (red.), Wielokulturowość: konflikt czy koegzystencja, Warszawa.

Sadowski A. (2014), Mniejszości narodowe i etniczne RP w perspektywie społeczeństwa pluralistycznego, „Studia Humanistyczne” t. 13, nr 3.

Siegień-Matyjewicz A. J. (2011), Prawo do dwujęzyczności - zgoda czy konflikt? Raport $z$ badań dotyczących dwujęzyczności osób pochodzenia białoruskiego zamieszkujacych tereny wschodniego Podlasia, „Pogranicze. Studia Społeczne”, t. 17.

Szul R. (2009), Język, naród, państwo. Język jako zjawisko polityczne, Warszawa.

The language rights of persons belonging to national minorities under the Framework Convention (2012) „Thematic Commentary”, nr 3, Strasbourg, Council of Europe - Advisory Committee on the Framework Convention for the Protection of National Minorities, July.

Trosiak C. (2013), Dyskusja i spory wokół wprowadzania podwójnych nazw miejscowości na terenie Śląka Opolskiego, „Przegląd Politologiczny”, nr 2. 
Ustawa z 6 stycznia 2005 r. o mniejszościach narodowych i etnicznych oraz o języku regionalnym (2005), Dz. U. nr 17, poz. 141.

Tuan Y-F. (1987), Przestrzeń i miejsce, Warszawa.

Tuan Y-F. (1991), Language and the Making of Place: A Narrative - Descriptive Approach, "Annals of the Association of American Geographers", t. 81, nr 4.

Wicherkiewicz T. (2014), Regionalne języki kolateralne Europy - porównawcze studia przypadku z polityki językowej, Poznań.

Wójcikowska K. (2013), Mniejszość litewska w Polsce, „Infos”, nr 7, Warszawa.

Wójcikowska K. (2014), Walka o miejsca pamięci w przestrzeni dwunarodowej gminy Sejny, „Pogranicze. Studia Społeczne”, t. 23.

Vasilevich H. (2014), Belorusians in Poland: Assimilation not implied by Law, „ECMI Working Paper", nr 80, October.

\section{SUMMARY}

\section{Ethnic "flagging" of the social reality. Problems of introducing additional place-names in minority languages in Poland}

In the article I try to analyze some problems of institutionalization of additional place names in minority languages in Poland. Regulations concerning these issues didn't exist in the Polish law until the adoption of the Act on National and Ethnic Minorities and Regional Language in 2005. The implementation of bilingual regulations had been the real and difficult phenomenon for the local administration and the public opinion but 1211 minority place names were established to the end of 2015. It wasn't a simple adaptation of legal regulations but there was always connected with the history of presence of minority group and its language and culture in the region as well as the memory of Polish - minority relations. Therefore, the "bilingual signs" were often described in terms of "ethnic flagging", favoring the minority group and defined through the prism of the fulfillment of its "ethnic" expectations. It has also meant the changing perception of the status of these communities in local community, shifting from "marginal" to the status of the "local co-host".

KEYWORDs: national minorities in Poland - linguistic rights of persons belonging to national minorities - additional place names in minority languages - local communities 